\title{
The Role of Religiosity on The Influence of Muslim Customer Perceived Value To Customer Satisfaction of Islamic Banking
}

\author{
1Yayuk Sri Rahayu \\ ${ }^{1}$ State Islamic University of Maulana Malik Ibrahim Malang, Malang, Indonesia \\ yayuk@pbs.uin-malang.ac.id
}

\begin{tabular}{|c|c|}
\hline Article Info & bstract \\
\hline $\begin{array}{l}\text { Article History } \\
\text { Received: July 12, } 2018 \\
\text { Accepted: September 30, } \\
2018\end{array}$ & \multirow{2}{*}{$\begin{array}{l}\text { The successfull of Islamic Banking on the global market depends on the } \\
\text { company's commitment to provide excellent service to their customers. The } \\
\text { concept of Muslim customer perceived value (MCPV) is composed of six } \\
\text { dimensions that consists of quality, price, emotional value, social value, } \\
\text { Islamic phisical attribute, and Islamic non phisical attribute. The purposes of } \\
\text { this research are to determine the influence of MCPV to customer satisfaction } \\
\text { of Islamic Banking at Malang Raya dan the role of religiosity in moderating } \\
\text { those effects. One hundred and four respondents, who are customers of } \\
\text { Islamic Banking, were involved in this research. Accidental sampling was } \\
\text { used as sampling technique and instrument was tested by validity and } \\
\text { reliability testing. Futhermore, data were analized by moderated regression } \\
\text { analysis (MRA). The results of this research shows (1) Simoultaneously, } \\
\text { Muslim customer perceived value (MCPV) influences the customer } \\
\text { satisfaction and partially, there are only three variables that influence } \\
\text { customer satisfaction such as price, social value, and Islamic non phisical } \\
\text { attribute. Other variables such as quality, emotional value, and Islamic } \\
\text { phisical attribute does not influence customer satisfaction; (2) Religiosity as } \\
\text { a moderating variable on the influence Islamic non phisical attribute to the } \\
\text { customer satisfaction. The moderating effect is streghtening the existing } \\
\text { influence. }\end{array}$} \\
\hline $\begin{array}{l}\text { Keywords } \\
\text { Muslim Customer Perceived } \\
\text { Value (MCPV); Customer } \\
\text { Satisfaction; Religiosity }\end{array}$ & \\
\hline & \\
\hline
\end{tabular}

\section{INTRODUCTION}

The Islamic financial system especially sharia banking has become an interesting discussion topic among financial practitioners. Islamic bank is an Islamic Financial Institution, and more than a bank (beyond banking), based on Al-Qur'an and Hadith. The banking practice refers to the principle of muamalah which explains something can be done unless there is not a prohibition in the Qur'an and the Hadith that organize the relationships between humanities related to economic, social, and politics (Ikatan Bankir Indonesia, 2014). With the majority Muslim population in Indonesia, sharia banking actually has a huge opportunity to grow and develop. Many people predict that this financial industry will experience rapid growth in line with the increasing public awareness of sharia banking (Danupranata, 2015). However, this prediction is not in line with the actual growth of sharia banking because the penetration of sharia banking assets in Indonesia is still around 4.58\% (Setyobudi et al, 2015). This shows that the acceptance of society to sharia banking is still not satisfactory.

To win the competition, the bank must provide more value for its customers such as the quality services because the quality attribute has become a highly considered element in consumer valuation of the bank (Al Mutawa \& Ibrahim, 2013). The key to success in winning the competition lies in the ability of banks to provide total customer 
value that can satisfy customers through the delivery of quality products at competitive prices (Hasan, 2010). The value of the customer or customer perceived value is the customer's perception of the value in which the company should consider the value in developing the product and its services so that in accordance with what is expected by customers.

Although many researchers have conducted research on the effect of perceived value on customer satisfaction and loyalty, research that focuses on Muslim customer perceived value (MCPV) is still rare. Eid and Gohary (2014) developed the concept of Muslim customer perceived value (MCPV). They developed a MCPV measurement scale of 24 items then grouped into six dimensions: quality, price, emotional value, social value, Islamic physical attribute values and Islamic nonphysical attribute values. In further research, both researchers continued their research on the influence of these six dimensions on the satisfaction of Muslim consumers. The results of their research found that the six dimensions of MCPV have a positive effect on Muslim consumer satisfaction (Eid \& Gohary, 2015). Rahayu (2016) found that there are three variables that have an effect on customer satisfaction, namely emotional value, social value, and Islamic nonphysical attribute. The other three variables of quality, price, and Islamic physical attributes have no effect on customer satisfaction of sharia banking. There is still a lack of research that specializes in the concepts and values of Muslim consumers; therefore, this issue should become the basis for further research in order to test and develop existing concepts.

Mokhlis (2009) states that Muslim consumers have unique characteristics when they decide to buy something; they always consider the doctrine of their religion, which is Islam. Furthermore, religiosity is recognized as one of the most important cultures that influence consumers' behavior (Ied, 2013; Zamani-Farahani \& Henderson, 2010; Zamani-Farahani \& Moses, 2012). According to Ateeq-Ur-Rehman (2010), religiosity affects the adoption of new products by Muslim consumers through influencing their beliefs about what products they should adopt. Religiosity also has a significant role in influencing consumer and social behavior (Khraim, 2010; Mukhtar \& But, 2012). In addition, the results of research by Youssef (2015) on Islamic banking in Egypt reveal that religiosity affects the attitude of consumers of sharia banking in Egypt. Religiosity also moderates the influence of perceived value on customer satisfaction (Eid \& Gohary, 2015). In addition, Souiden and Rani (2015) state that religiosity has an indirect effect on the interest of purchasing sharia banking through attitudes toward the bank. However, Farraq and Hassan (2015) found different results with some previous studies that there was a negative relationship between religiosity with the attitude of Egyptian youth in determining fashion trends.

Based on the results of some earlier studies known that there are differences in those results especially on the effect of religiosity on customer satisfaction and behavior. This provides a gap for this study to examine more deeply about the role of religiosity on influencing consumer satisfaction and behavior. This study aims to determine the influence of Muslim customer perceived value on customer satisfaction of sharia banking and the role of religiosity in moderating the existing influence.

\section{METHOD}

The study population included all customers of Sharia banking in Malang. Total sample of 104 respondents was selected by accidental sampling technique. To test the research hypothesis, data were analyzed by moderated regression analysis (MRA). Respondents in this study consisted of 60 men and 44 women, with minimum age is 15 
years old. Majority of them are students and private employees, and most of them had become customers of sharia banking for less than 2 years $(46.2 \%)$.

RESULT

Effect of Muslim customer perceived value on customer satisfaction Tabel 1. Uji signifikansi Parameter Individual (Uji t) Coefficients $^{\mathrm{a}}$

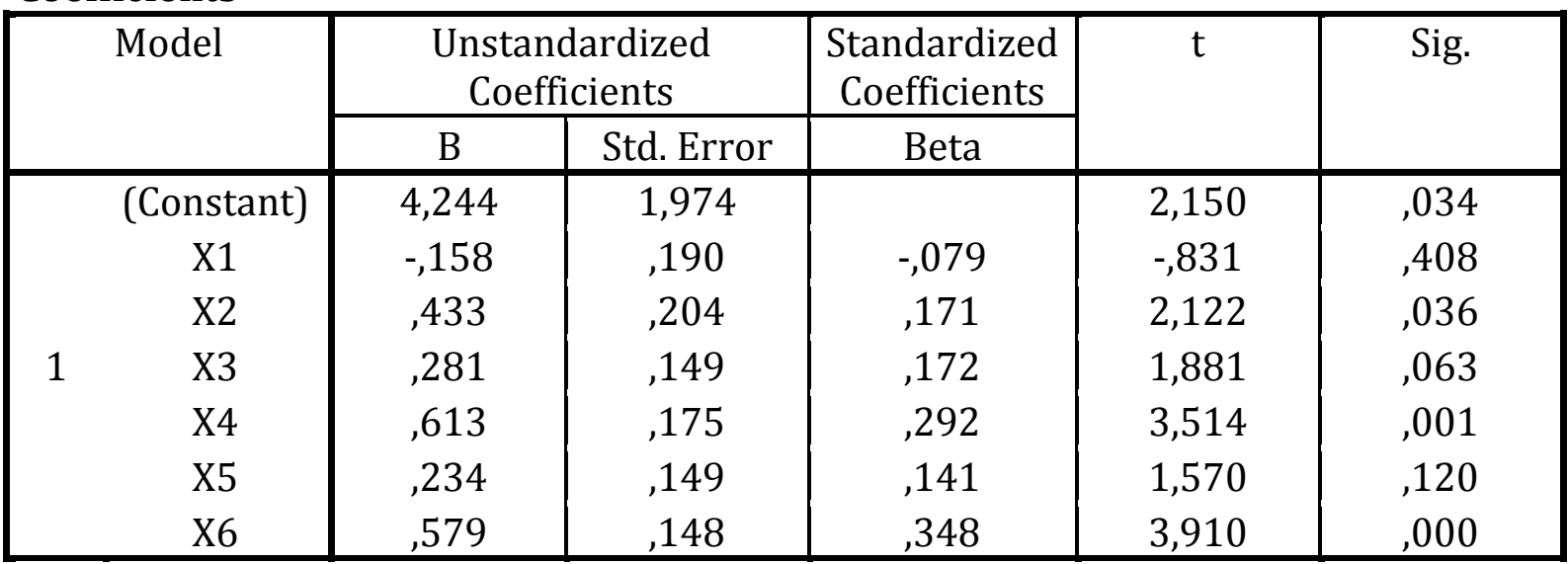

a. Dependent Variable: Y

Source: data processed by researchers (2017)

Table 1 shows three variables that have an effect on customer satisfaction include price, social values, and Islamic non-physical attributes of variables. The other three variables of quality, emotional values, and Islamic physical attributes do not affect customer satisfaction.

The role of religiosity on the influence of Muslim customer perceived value to customer satisfaction of Islamic banking

Tabel 2. Moderated regression analysis

Coefficients $^{\mathbf{a}}$

\begin{tabular}{|c|c|c|c|c|c|}
\hline \multirow{2}{*}{ Model } & \multicolumn{2}{|c|}{$\begin{array}{c}\text { Unstandardized } \\
\text { Coefficients }\end{array}$} & $\begin{array}{c}\text { Standardized } \\
\text { Coefficients }\end{array}$ & Sig. \\
\cline { 2 - 4 } & B & Std. Error & Beta & & \\
\hline \multirow{2}{*}{ (Constant) } & 1,171 &, 385 & & 3,040 &, 003 \\
X1.Z &, 013 &, 094 &, 098 &, 137 &, 891 \\
X2.Z &,- 141 &, 115 & $-1,151$ & $-1,229$ &, 222 \\
X3.Z &,- 142 &, 105 & $-1,196$ & $-1,357$ &, 178 \\
X4.Z &, 083 &, 118 &, 742 &, 699 &, 486 \\
X5.Z &,- 012 &, 096 &,- 097 &,- 129 &, 898 \\
X6.Z &, 216 &, 091 & 1,797 & 2,371 &, 020 \\
X1 &,- 082 &, 359 &,- 082 &,- 228 &, 820 \\
X2 &, 660 &, 457 &, 780 & 1,443 &, 153 \\
X3 &, 710 &, 425 &, 867 & 1,672 &, 098 \\
X4 &,- 160 &, 466 &,- 228 &,- 343 &, 733 \\
X5 &, 135 &, 394 &, 162 &, 342 &, 733 \\
X6 &,- 630 &, 381 &,- 757 & $-1,654$ &, 102 \\
\hline
\end{tabular}




\section{a. Dependent Variable: Y}

Source: data processed by researchers (2017)

Table 2 shows that religiosity moderates the influence of Muslim customer perceived value (MCPV) to customer satisfaction, especially on Islamic non physical attributes variable by streghtening those effects.

The research results support earlier research. But, these are less consistent with (Eid \& Gohary, 2015) who found that six dimensions of Muslim Customer Perceived Value (MCPV) consisting of quality, price, emotional value, social value, Islamic physical attribute value and Islamic nonphysical attributes value have a positive effect on Muslim consumer satisfaction. In addition, results of this study are also slightly different from previous research that there are three variables that partially affect customer satisfaction, namely emotional value, social value, and Islamic nonphysical attributes variables (Rahayu, 2016). This study shows that price also affects on customer satisfaction.

The result of current research also shows that religiosity moderate the influence of one variable of Muslim customer perceived value to customer satisfaction of syariah banking, which is on Islamic non physical attribute variable by strengthening existing influence. The results of this study support the previous research which suggested that religiosity moderates by strengthening the influence of Islamic physical attributes and Islamic non-physical attributes on customer satisfaction (Eid \& Gohary, 2015).

The results of this study also support some previous empirical studies which stated that the level of religiosity affects the behavior of consumers, including in choosing Islamic banking as their partner. People with a higher level of religiosity in decisionmaking and behavior will take account of the rules of religion or belief. They will only consume or buy goods and services that are allowed by religion as a form of devotion to their religion. Even this consideration is not only on the final goods or services but to the process of how the product is made.

In the context of Islamic banking, customers assess the overall quality, especially on the aspects of shariah compliance or compliance with the rules of sharia. This rule is not only on the contract side but concerns other things such as processes. One example is that customers judge on how an employee of a sharia bank can behave in accordance with sharia, the way they offer products, how to communicate, and their level of knowledge about sharia rules (Diana, 2008). In the teachings of Islam based on AlQur'an and Hadith, it is determined that in offering and promoting products, a Muslim must be honest, should not be exaggerated with perjury and bombastic but must be realistic, and convey the advantages and disadvantages of the product being sold. So that will establish a harmonious relationship between the seller and the buyer. This is also true in the sharia banking industry. One that distinguishes sharia banking with conventional banking is the form of relationship between the bank and the customer. If in conventional banking the form of the relationship is creditor and debtor, the relationship in sharia banking is as partners.

\section{CONCLUTION}

Based on results and research discussion, the conclusion can be stated below.: (1) Three variables affect customer satisfaction, namely price, social values, and Islamic nonphysical attributes. The other three variables of quality, emotional values, and Islamic physical attributes do not affect customer satisfaction. (2) The religiosity moderates the influence of Muslim customer perceived value (MCPV) to customer satisfaction, especially on Islamic non physical attributes variable by streghtening those effect. 


\section{REFERENCE}

[1] Al Mutawa, Saeed A.G \& Mohamed E. Ibrahim. 2013. Effects of Gender and Personality Traits of Front-Desk Employees on Customer's Assessment of Service Quality: Evidence from Islamic Banks in the UAE. International Journal of Business and Management, Vol 8, No 15.

[2] Ateeq-Ur-Rehman, M.S. 2010. The Relationship between Religiosity and New Product Adoption. Journal of Islamic Marketing, 1 (1). 63-69.

[3] Chang, Hsin Hsin, Hsin-Wei Wang. 2011. The moderating effect of customer perceived value on online shopping behavior. Online Information Review, Vol. 35 Iss: 3, pp.333 - 359 .

[4] Danupranata, Gita. 2015. Manajemen Perbankan Syariah. Penerbit Salemba Empat. Jakarta.

[5] Diana, Ilfi Nur. 2008. Hadits-hadits Ekonomi. UIN Malang Press. Malang

[6] Eid, Riyad. 2013. Integrating Muslim Customer Perceived Value, satisfaction, loyalty and Retention in the Tourism Industry: An Empirical Study. International Journal of Tourist Research.

[7] Eid, Riyad, Hatem El-Gohary. 2014. Muslim Tourist Perceived Value in the Hospitality and Tourism Industry. Journal of travel research.

[8] ..................... 2015. The Role of Islamic Religiosity on Relationship between Perceived Value and Tourist Satisfaction. Tourism Management, 46, P 477-488.

[9] Hasan, Ali. 2010. Marketing Bank Syariah. Ghalia Indonesia. Bogor.

[10] Ikatan Bankir Indonesia. 2014. Memahami Bank Syariah : Modul Sertifikasi Tingkat I General Banking Syariah. PT. Gramedia. Jakarta.

[11] Khraim, Hamza. 2010. Measuring Religiosity in Consumer Research From an Islamic Perspective, Journal of Economic and Administrative Sciences, Vol. 26 Iss: 1, pp.52 - 78

[12] Kotler, Philip dan Kevin Lane Keller. 2007. Manajemen Pemasaran. Edisi Kedua Belas. Indeks : Jakarta

[13] Mokhlis, S. 2009. Relevancy and Measurement of Religiosity in Consumer Behavior Research. International Business Research, 2 (3), 75-84.

[14] Mukhtar, Arshia, Muhammad Mohsin Butt. 2012. Intention to choose Halal products: the role of religiosity. Journal of Islamic Marketing, Vol. 3 Iss: 2, pp.108 - 120

[15] Rahayu, Yayuk Sri. 2016. Muslim Customer Perceived Value (MCPV) dan Pengaruhnya Terhadap Kepuasan Nasabah Perbankan Syariah di Kota Malang. Proceedings. International Conference of Islamic Economics and Business (ICONIES). UIN Maulana Malik Ibrahim Malang.

[16] Setyobudi, Wahyu Tri, Sudarso Kaderi Wiryono, Reza Ashari Nasution dan Mustika Sufiati Purwanegara. 2015. Exploring implicit and explicit attitude toward saving at Islamic bank, Journal of Islamic Marketing, Vol. 6 Iss 3 pp. 314 - 330.

[17] Souiden, Nizar dan Marzouki Rani. 2015. " Consumer attitudes and purchase intentions toward Islamic banks: the influence of religiosity ", International Journal of Bank Marketing, Vol. 33 Iss 2 pp. 143 - 161.

[18] Youssef, Mariam Mourad Hussein Abou, Wael Kortam , Ehab Abou-Aish, Noha ElBassiouny. 2015. Effects of religiosity on consumer attitudes toward Islamic banking in Egypt, International Journal of Bank Marketing, Vol. 33 Iss: 6, pp.786 - 807. 